\title{
The effect of environmental temperature on the performance and health of the pre-ruminant and ruminant calf
}

\author{
BY J. H. B. ROY, I. J. F. STOBO, HELEN J. GASTON, \\ P. GANDERTON AND SUSAN M. SHOTTON \\ National Institute for Research in Dairying, Shinfield, Reading RG2 $9 A T$ \\ AND D. C. OSTLER \\ Regional Veterinary Investigation Centre, Ministry of Agriculture, \\ Fisheries and Food, Reading RGI $6 D T$
}

$$
\text { (Received } 9 \mathfrak{7 u l y} \text { 1970-Accepted } 24 \text { May 1971) }
$$

I. Eighty bull calves, comprising forty-eight Ayrshire and sixteen each of the Friesian and Jersey breeds, were used in a randomized block experiment. Forty calves were maintained at a mean environmental temperature of $21^{\circ}$ and forty at $14.5^{\circ}$. Within each temperature, twenty calves were reared from birth on a liquid milk substitute diet (pre-ruminant calves) and twenty were weaned at $35 \mathrm{~d}$ of age on to dry food (ruminant calves). Each type of diet was given either ad lib. or at a restricted level. The calves were slaughtered at about roo d of age.

2. The incidence of a high rectal temperature $\left(>39.33^{\circ}\right)$ was greater for the pre-ruminant than for the ruminant calves during the first $14 \mathrm{~d}$ of life and throughout the whole experimental period, and was higher for calves at an environmental temperature of $2 \mathrm{I}^{\circ}$ than for those kept at $14.5^{\circ}$. During the experimental period as a whole, but not during the first $14 \mathrm{~d}$ of life, the incidence of diarrhoea was greater for the pre-ruminant calves. Mean rectal temperature was higher for the pre-ruminant calves and also higher for the calves reared at the high environmental temperature.

3. The incidence of lung lesions at slaughter was significantly higher in the ruminant than in the pre-ruminant calves, and tended to be higher at the high environmental temperature. There was a highly significant positive relationship between severity of lung lesions and incidence of a high rectal temperature $\left(>39^{\circ} 33^{\circ}\right)$ and mean rectal temperature. Jersey and Friesian calves, but not Ayrshire calves, showed increased severity of lung lesions with increasing relative humidity at the low environmental temperature. When the results at the 'high' environmental temperature were combined with those obtained in an earlier experiment, the severity of lung lesions for Jersey and Friesian calves increased with decreasing relative humidity. At the 'high' but not at the 'low' temperature, severity of lung lesions was inversely related to skin weight $/ \mathrm{kg}^{0 \cdot 73}$.

4. Live-weight gain was much lower for the ruminant calves, but was unaffected by environmental temperature. Daily dry-matter intake from liquid diets given $a d$ lib. did not differ between breeds at the same live weight. In contrast, daily dry-matter intake from dry food given ad lib. was greatest for the Jersey and lowest for the Friesian at the same live weight. The same daily dry-matter intake from liquid as from dry diets was achieved at similar percentages of mature weight for the three breeds. Relative weight gain within type of diet was similar for Jersey and Ayrshire calves, but tended to be higher for the Friesian calves.

5. Carcass weight, carcass weight ${ }^{0.73}$, perirenal fat deposition, skin weight and killing out percentage were much lower for the ruminant calves. When adjusted for differences between treatment means for carcass weight $\mathrm{t}^{0.73}$, perirenal fat deposition was greater at the $a d$ lib. levels of intake and was $36 \%$ greater for pre-ruminant calves given milk substitute $a d$ lib. at an environmental temperature of $21^{\circ}$ than for those maintained at $14.5^{\circ}$.

6. It is concluded that there is no advantage to be gained from rearing calves at an environmental temperature above $14.5^{\circ}$, unless increased fat deposition is required in veal calves.

There is little evidence that the artificial heating of calf-houses is economic, except for the production of veal from pre-ruminant calves for which a temperature of $15^{\circ}-20^{\circ}$ has been recommended (Haartsen, van Hellemond, van der Wal \& van 
Weerden, 1967). At lower levels of milk intake, Gonzalez-Jimenez \& Blaxter (1962) found that the critical temperature of the Ayrshire calf given 41 milk daily was $12.8^{\circ}$ at $3 \mathrm{~d}$ of age and declined to $8 \cdot 2^{\circ}$ on the 20 th day. Increasing the milk intake to 61 daily did not reduce the critical temperature to below $7-8^{\circ}$ despite the higher heat production of the calves. On the basis of this evidence, it has been suggested that the temperature of a calf-house should be maintained above $12 \cdot 8^{\circ}$ if it contains newborn calves.

To obtain more information on the effect of environmental temperature on the performance of both ruminant and pre-ruminant calves, an experiment was made to compare the effect of ambient temperatures of $10^{\circ}$ and $20^{\circ}$ on calves, either given liquid diets alone, or weaned on to dry food at 5 weeks of age. Both diets were given either restricted or $a d l i b$. Owing to the absence of air-conditioning, the actual mean ambient temperatures were $14.5^{\circ}$ and $21^{\circ}$.

\section{METHODS}

\section{Plan of experiment}

The experiment of randomized block design was done between October 1965 and December 1967 , largely during the winter months, and consisted of eight treatments in each of ten blocks. Six blocks were of the Ayrshire breed and two blocks each of the Jersey and Friesian breeds. The calves were removed from their dams before suckling and were placed on experiment within $8 \mathrm{~h}$ of birth.

The treatments, together with the mean ambient temperatures to which the calves were exposed, were:

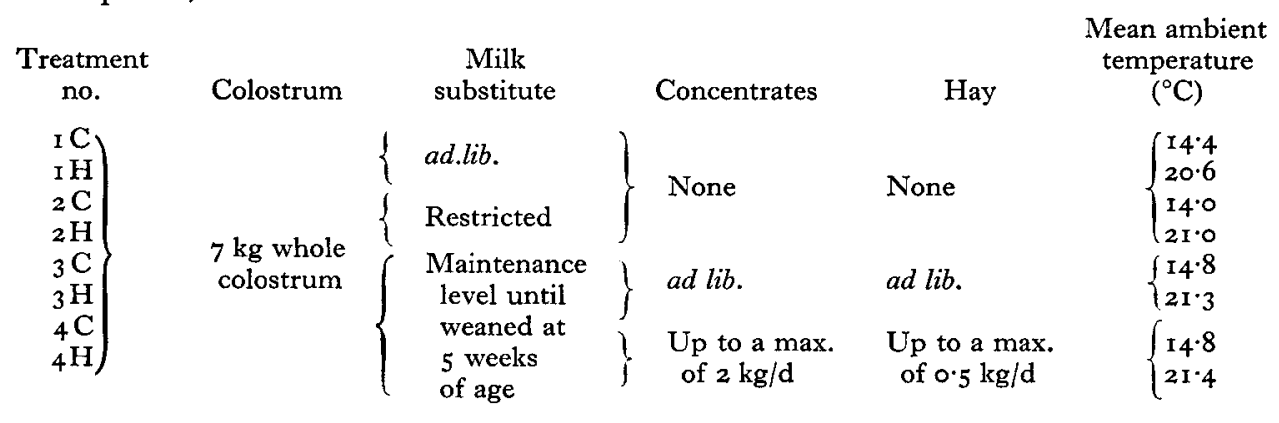

Diets

Colostrum. Within $48 \mathrm{~h}$ of birth, each calf was given $7 \mathrm{~kg}$ whole colostrum obtained from the first two milkings after parturition of Jersey, Ayrshire and Friesian cows.

Milk substitute. The chemical composition of the diet is given in Table I (a). The preparation of the diet and the level of supplementation with vitamins and minerals were as described by Roy, Stobo, Gaston, Ganderton, Shotton \& Thompson (1971).

All calves on treatments $I$ and 2, that received only the milk substitute diet, were given a total supplement of $1500 \mathrm{mg} \mathrm{Fe}$ in the form of $5 \mathrm{ml} \mathrm{Fe}$ dextran, containing I00 mg Fe/ml (Imposil 200; Fisons Pharmaceuticals Ltd, Loughborough), injected intramuscularly on the $7_{\text {th, }} \mathbf{1}_{\text {th }}$ and 21st days of age, as described by Roy, Gaston, Shillam, Thompson, Stobo \& Greatorex (1964). 
The milk substitute was given ad lib. to calves on treatment $\mathrm{r}$. On treatment 2 , milk intake was restricted to a level designed to produce a live-weight gain of $\mathrm{I} \mathrm{kg} / \mathrm{d}$, the amount of milk being calculated on the basis that the milk substitute had a calorific value of $4.97 \mathrm{kcal}$ digestible energy/g dry matter. The maintenance requirement of the calf was assumed to be $52.4 \mathrm{kcal}$ digestible energy $/ \mathrm{kg}$ live weight (Blaxter \& Wood,

\section{Table 1. Composition of the diets}

(a) Milk substitute

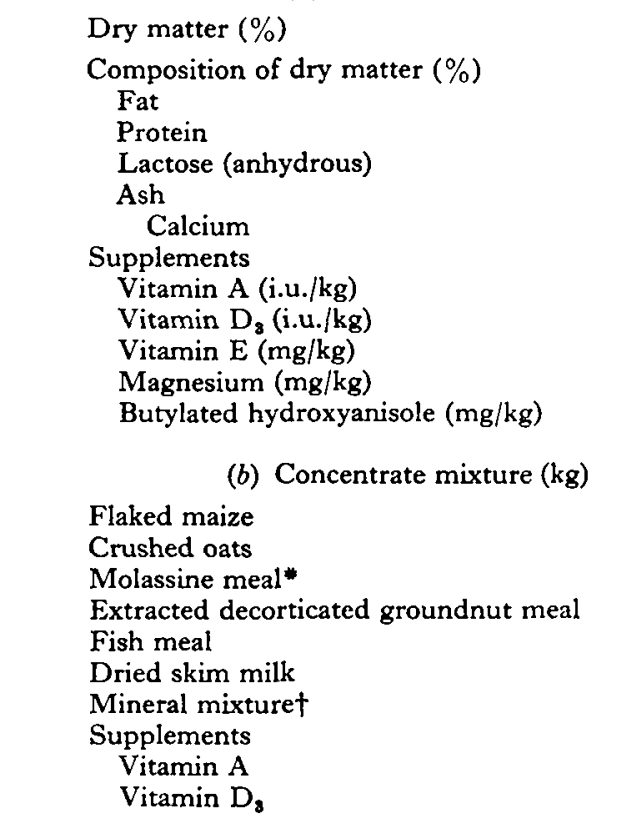

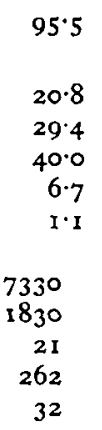

$47 \cdot 5$
$23 \cdot 8$
$10 \cdot 0$
$9 \cdot 4$
$3 \cdot 1$
$6 \cdot 3$
$1 \cdot 0$
4400 i.u. $/ \mathrm{kg}$ diet
I 100 i.u./kg diet

(c) Chemical composition of concentrate mixture and hay

$\begin{array}{lcc} & \begin{array}{c}\text { Concentrate } \\ \text { mixture }\end{array} & \text { Hay } \\ \text { Dry matter (\%) } & 84.6 & 84.0 \\ \text { Composition of dry matter (\%) } & & \\ \text { Ether extractives } & 2 \cdot 3 & 1 \cdot 4 \\ \text { Crude protein } & 18.8 & 9 \cdot 6 \\ \text { Nitrogen-free extract } & 69.7 & 49.4 \\ \text { Crude fibre } & 4.1 & 31 \cdot 7 \\ \text { Ash } & 5 \cdot 1 & 7.9 \\ \text { Calcium } & 0.7 & 0.6\end{array}$

- Contained $75 \%$ molasses and $25 \%$ peat moss (Molassine Co. Ltd, Greenwich, London, SE ro). † Calcium $17.4 \%$, phosphorus $11.4 \%$, copper $1800 \mathrm{ppm}$, cobalt $300 \mathrm{ppm}$, manganese $510 \mathrm{ppm}$, iodine $0.025 \%$, sulphur $0.75 \%$, iron $0.24 \%$, sodium + chlorine $30 \%$.

1951) and the production requirement $3020 \mathrm{kcal}$ digestible energy $/ \mathrm{kg}$ weight gain

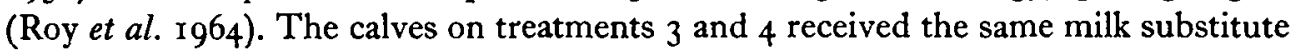
at a maintenance level until 5 weeks of age and were then weaned abruptly.

Concentrates, hay and water. The composition of the concentrate mixture is given in Table $\mathrm{I}(b)$ and the chemical analysis of the concentrate mixture and of the hay, 
obtained from monthly samples, is given in Table $\mathrm{I}(c)$. Concentrates, hay and water were offered from $I$ week of age to calves on treatments 3 and 4 . In treatment 3 the concentrates and hay were offered $a d l i b$. throughout the experiment, whereas in treatment 4 they were offered $a d l i b$. up to a maximum of $2 \mathrm{~kg}$ concentrates and $0.5 \mathrm{~kg}$ hay daily.

\section{Calves}

The collection and management of the calves were as described by Roy, Stobo, Gaston \& Greatorex (1970) except that the calves were housed under 'controlled' environmental conditions in galvanized metal pens, having galvanized expandedmetal floors. The milk substitute was given to the calves twice daily at 08.15 and r6.30 hours, the diets being hand-fed or automatically dispensed into polyethylene buckets (Roy, Stobo \& Gaston, I965); the refused food was removed and the weight recorded after about $20 \mathrm{~min}$. Concentrates and hay were on offer continuously for calves given dry food ad lib.

The records kept were the same as those described by Roy et al. (1964). The calves on treatment I were slaughtered after reaching $22 \%$ of mature cow weight of the breed (Foot \& Roy, 1967); those on treatment 2, in which the milk substitute diet was restricted, were slaughtered after the weight of the calves reached $77 \mathrm{~kg}$ above the mean birth weight of the breed; those given dry diets in treatments 3 and 4 were slaughtered after they had reached $98 \mathrm{~d}$ of age. The slaughter weights $(\mathrm{kg})$ for the calves given liquid diets were:

$\begin{array}{lcc} & \begin{array}{c}\text { Treatment } \\ \text { (ad lib.) }\end{array} & \begin{array}{c}\text { Treatment 2 } \\ \text { (restricted) }\end{array} \\ \text { Jersey } & 90 & \text { I05 } \\ \text { Ayrshire } & \text { I 18 } & \text { I I I } \\ \text { Friesian } & \text { I36 } & \text { I 18 }\end{array}$

The calves were slaughtered on the Tuesday after the appropriate age or weight was reached. Calves on treatments $I$ and 2 were given no milk on the morning of slaughter and only half their normal allowance at the evening feed on the day before slaughter. Concentrates, hay and water were removed at 17.00 hours on the day before slaughter of calves on treatments 3 and 4 . The weights of skin, carcass and perirenal fat were recorded, and the degree of consolidation in the tissues of the lungs was assigned a score (Roy, Stobo \& Gaston, 1970).

\section{Calf-house}

The calf-house, constructed with insulated sandwich construction roof and cavity walls, consisted of two identical units, measuring $12.2 \times 12.2 \mathrm{~m}$, each containing twenty-four pens, measuring $\mathrm{I} \cdot 8 \times \mathrm{I} \cdot 2 \mathrm{~m}$, arranged in four rows of six pens. The volume of air space in each unit was about $48 \mathrm{I} \mathrm{m}^{3}$, giving a capacity of $20 \mathrm{~m}^{3} /$ calf.

Each unit was heated by four fan heaters located at the end of the passage-ways between the pens, using steam at a pressure of $345 \times 10^{3} \mathrm{~N} \mathrm{~m}^{-2}\left(50 \mathrm{lb} / \mathrm{in}^{2}\right)$, each having an output of $17.97 \times 10^{3} \mathrm{~J} \mathrm{~s}^{-1}(6 \mathrm{r} 300 \mathrm{BTU} / \mathrm{h})$ at an entering air temperature of $2 \mathrm{r} \cdot \mathrm{I}^{\circ}$, the heater fans being controlled by thermostats. 
Inlet ventilation was through adjustable hopper windows and outlet ventilation was by two $0.46 \mathrm{~m}$ ( $18 \mathrm{in}$ ) fans fitted in the roof to each unit over the passage-way; each fan had a maximum output of $1.65 \mathrm{~m}^{3} \mathrm{~s}^{-1}\left(3500 \mathrm{ft}^{3} / \mathrm{min}\right)$ at $1400 \mathrm{rev} / \mathrm{min}$. The fans, which had variable speed control, were run at full capacity, except in extremely cold weather, giving an extraction rate of about 24 air changes $/ h$.

For the first three replications of the experiment, ambient temperature only was recorded, but thereafter temperature and relative humidity were recorded at $180 \mathrm{~s}$ intervals by means of a recorder (Foster Instrument Co. Ltd, Letchworth), based on potentiometer readings from dry and wet bulb thermometers.

Environmental control. The planned temperature of $20^{\circ}$ was maintained without difficulty, the mean temperature for the forty calves on these treatments being $21^{\circ}$, with the mean values for individual calves ranging from 18.6 to $22.8^{\circ}$. However, in the other unit it was not possible to keep the temperature down to $10^{\circ}$, since air-conditioning facilities were not available. There was also a considerable diurnal variation in temperature in the 'cold' unit, owing to the difficulty of cooling the unit during the day-time. Moreover, owing to the replacement of some calves (see below), a few calves were present in the unit during a period of warm weather. Thus the mean temperature for the forty calves on these treatments was $14.5^{\circ}$, with mean values for individual calves ranging from $12 \cdot 7$ to $18.0^{\circ}$.

The mean relative humidities and ranges to which each calf of the seven final replications of the experiment was exposed were $48 \%(40-64 \%)$ for the unit with an average ambient temperature of $2 \mathrm{I}^{\circ}$, and $64 \%\left(55^{-76} \%\right)$ for the unit with an average ambient temperature of $14.5^{\circ}$. The absolute humidity, based on the mean values, was slightly higher in the 'hot' unit, namely $8.75 \mathrm{~g} / \mathrm{m}^{3}$ and $7.85 \mathrm{~g} / \mathrm{m}^{3}$ of water vapour in the 'hot' and 'cold' units respectively.

\section{RESULTS}

\section{Health}

Mortality. In the 'cold' unit, four calves died and were replaced; two were Jerseys on treatment $\mathrm{I}$ and two were Ayrshires on treatment 2. One Jersey and one Ayrshire died from an Escherichia coli septicaemia at 21 and $28 \mathrm{~d}$ of age respectively. The Jersey calf was nearly $18 \mathrm{~h}$ old before it received colostrum, owing to a delay by the farmer in the notification of its birth. The Ayrshire calf refused to take colostrum at its first feed. The second Jersey calf died at $123 \mathrm{~d}$ of age of a severe enteritis and pneumonia together with an interstitial nephritis; Pasteurella sp. was isolated from the lungs. The second Ayrshire calf died of mucosal disease at $28 \mathrm{~d}$ of age.

In the 'hot' unit, two Ayrshire calves and one each of the Jersey and Friesian breeds were replaced, representing one calf on each of the four treatments. The Friesian calf on treatment I became inappetent at $84 \mathrm{~d}$ of age, had an abscess on the right knee and a very significant rise in blood serum titre to mucosal disease virus at slaughter at I $20 \mathrm{~d}$ of age. The Ayrshire on treatment 2 was slaughtered at I d of age with a congenital abnormality of the posterior third of the ileum, resulting in complete obstruction of an abnormally narrow lumen. This calf appeared also to be double-muscled. 


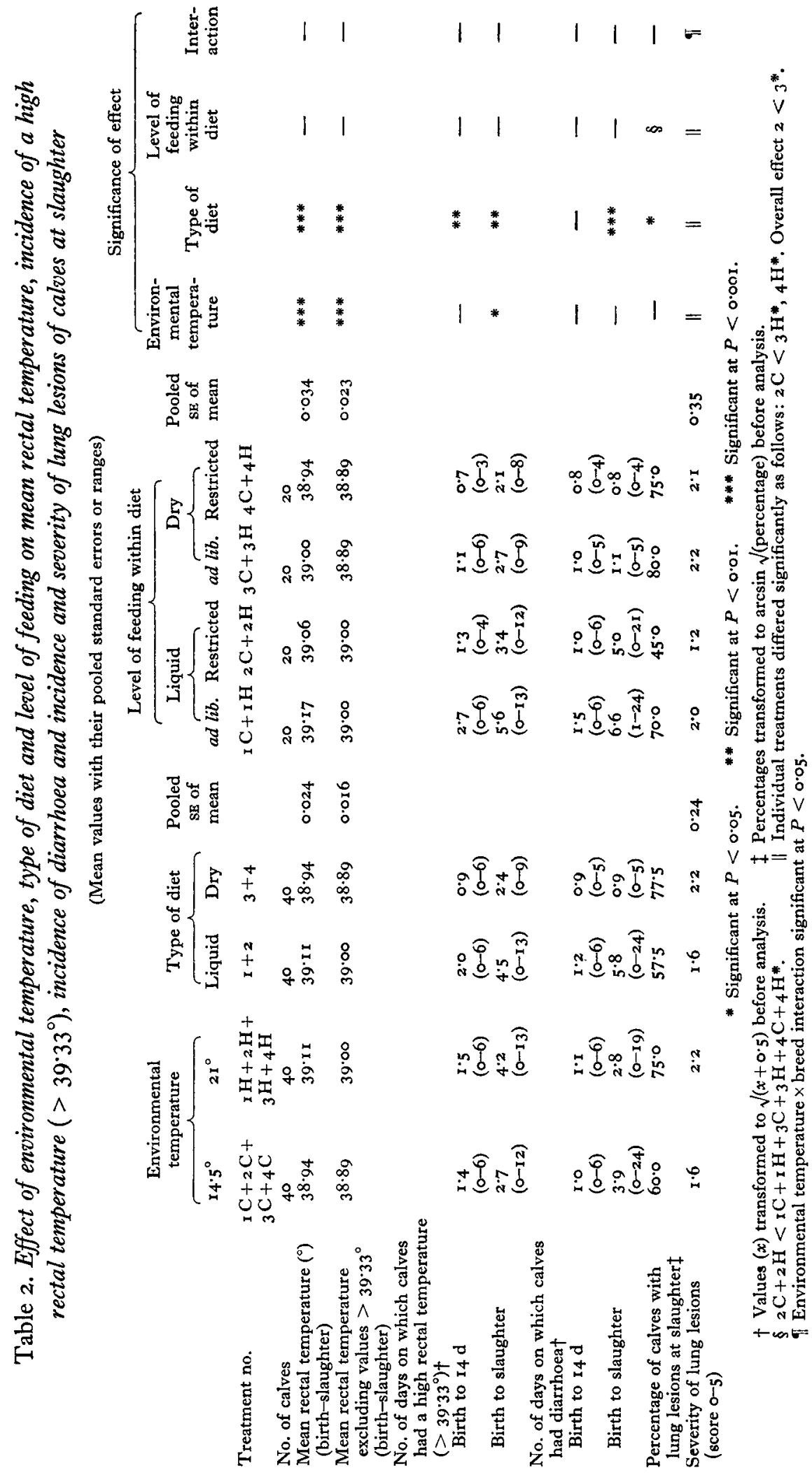


The Jersey calf on treatment 3 died at $78 \mathrm{~d}$ of age with lesions of pneumonia, possibly of viral origin, complicated by a secondary staphylococcal infection. The Ayrshire calf on treatment 4 died at $\mathrm{I} 8 \mathrm{~d}$ of age as a result of pneumonia.

Mean rectal temperature (Table 2). Mean rectal temperature was between $0 \cdot \mathrm{I}^{\circ}$ and $0.2^{\circ}$ higher for the pre-ruminant calves and a similar amount higher for the calves reared in the 'hot' unit, but was not significantly affected by level of feeding. Since the mean rectal temperature of calves on a particular treatment was likely to be affected by the incidence of a high rectal temperature, a comparison of mean rectal temperature, excluding all values above $39.33^{\circ}$, was made. After this adjustment, mean rectal temperature was still higher in the 'hot' unit and in the liquid-fed calves. Thus, these treatments, besides causing a higher incidence of pyrexia (see below), also resulted in a higher 'normal' rectal temperature.

Incidence of a high rectal temperature ( $\left.>39^{\circ} 33^{\circ}\right)$ (Table 2$)$. During the first $\mathrm{I}_{4} \mathrm{~d}$ of life, the incidence was higher for calves given milk substitute at high levels on treatments I and 2 than for those fed at a maintenance level on treatments 3 and 4 . During the whole experimental period the incidence of a high rectal temperature was greater for the pre-ruminant than for the ruminant calves and was greater for the calves reared in the 'hot' unit. Higher levels of feeding tended to result in a higher incidence of rectal temperatures $>39.33^{\circ}$ but the effect was not significant.

Incidence of diarrhoea (Table 2). During the first $\mathrm{I}_{4} \mathrm{~d}$ of life there was no difference between treatments in the incidence of diarrhoea, but during the whole experimental period a much higher incidence occurred with the pre-ruminant calves. Level of feeding had no effect. There was no relationship between the incidence of diarrhoea and the incidence of a high rectal temperature.

Incidence and severity of lung lesions at slaughter (Table 2). The incidence of lung lesions was significantly greater for the ruminant than for the pre-ruminant calves and tended to be greater in the 'hot' unit. Forty-five per cent of the pre-ruminant calves given milk substitute at the restricted level of intake had lung lesions at slaughter, compared with $75 \%$ for calves on the other three dietary regimens.

The severity of lung lesions reflected the trends observed for incidence of lung lesions. The pre-ruminant calves given milk substitute at a restricted level and reared in the 'cold' unit (treatment $2 \mathrm{C}$ ) had significantly less severe lesions than calves reared in the 'hot' unit and given dry food either $a d$ lib. or at the restricted level of intake (treatments $3 \mathrm{H}$ and $4 \mathrm{H}$ respectively).

Irrespective of dietary treatment, there was a significant $(P<0.05)$ environmental temperature $\times$ breed interaction, since the severity of lesions in Ayrshire calves was similar in the 'hot' and in the 'cold' unit, but in Jerseys and Friesians the severity tended to be greater in the 'hot' than in the 'cold' unit.

Relationship of severity of lung lesions with rectal temperature. There was no relationship between the severity of lung lesions and the incidence of diarrhoea during the experimental period. However, a highly significant positive relationship existed between the severity of lung lesions and the incidence of a high rectal temperature $(b=0.764 \pm 0.2467, P<0.01)$ and also with mean rectal temperature $\left(b=2.45^{8} \pm\right.$ $0.6482, P<0.001)$ over the experimental period. After exclusion of temperatures 
$>39^{\circ} 33^{\circ}$, in calculation of the mean rectal temperature, the relationship with severity of lung lesions no longer existed.

Relationship of severity of lung lesions with relative humidity. A study was also made of the relationship between the severity of lung lesions and the relative humidity to which individual calves were exposed, within the 'cold' and 'hot' units separately. Because of the small numbers of calves of the Jersey and Friesian breeds, it was not possible to compare individual regression coefficients for each breed on each treatment. Consequently the $a d l i b$. and restricted treatments were pooled within liquid and dry diets for each breed. There was no significant difference in the slope or position of the regression within breeds. The regression for liquid and dry diets for each breed was therefore combined. There was no significant difference between breeds but there was a tendency for the lung lesions in Jersey and Friesian calves to increase in severity with increasing relative humidity in the 'cold' unit and with decreasing relative humidity in the 'hot' unit, whereas the opposite trend was observed for the Ayrshire breed. Somewhat similar relationships were established in another experiment in which calves of these three breeds were reared at a temperature of $22 \cdot 7^{\circ}$ (Roy et al. 1971). The overall regression coefficients from that experiment are presented, therefore, in addition to those obtained from the present experiment.

\begin{tabular}{|c|c|c|c|}
\hline \multirow[b]{2}{*}{ Environmental temperature $\left({ }^{\circ} \mathrm{C}\right)$} & \multicolumn{2}{|c|}{ Present experiment } & \multirow{2}{*}{$\begin{array}{c}\text { Roy et al. (I97I) } \\
22 \cdot 7\end{array}$} \\
\hline & $14 \cdot 5$ & $2 \mathrm{I}$ & \\
\hline $\begin{array}{l}\text { Jersey } \\
\text { Friesian } \\
\text { Ayrshire }\end{array}$ & $\begin{array}{r}0.133 \pm 0.0616 \\
0.250 \pm 0.1 \times 83 \\
-0.047 \pm 0.0767\end{array}$ & $\begin{array}{r}-0.177 \pm 0.1034 \\
-0.098 \pm 0.1054 \\
0.118 \pm 0.1011\end{array}$ & $\begin{array}{r}-0.176 \pm 0.0859 \\
0.065 \pm 0.1763 \\
0.020 \pm 0.3701\end{array}$ \\
\hline
\end{tabular}

Although the within-diets regression coefficients for the Jersey and Friesian breeds in the 'cold' unit were not quite significant owing to the small number of animals, when the results for the two breeds were combined the regression coefficient of severity of lung lesions on relative humidity was $0.174 \pm 0.0586$ (significant at $P<0.05)$.

Since, for calves kept in the 'hot' unit, there was no difference in slope or position of the regression within breeds between the results of the present experiment and those of the experiment of Roy et al. (1971), the results for the two experiments were combined. A significant $(P<0.05)$ regression coefficient of severity of lung lesions on relative humidity was obtained for the combined Jersey and Friesian calves of $-0.149 \pm 0.0529$. This value was significantly different $(P<0.01)$ from that obtained for Jersey and Friesian calves reared in the 'cold' unit.

For Ayrshire calves there was no difference in position or slope of any regressions obtained in the two experiments. The only significant regression coefficient for this breed was with pre-ruminant calves kept at $14^{\circ} 5^{\circ}$ in the present experiment, under which conditions there was an inverse relationship between severity of lung lesions and relative humidity $(b=-0.305 \pm 0.1210, P<0.05)$.

In the present experiment there was a significant $(P<0.05)$ inverse overall rela- 
tionship between severity of lung lesions and the skin weight per unit of metabolic body-weight ( $\left.\mathrm{kg}^{0.73}\right)$ at slaughter in the 'hot' but not in the 'cold' unit. There was no relationship between the severity of lung lesions and perirenal fat per unit of metabolic body-weight at slaughter.

\section{Dry-matter intake and weight gain}

The results for the pre-ruminant calves and the early-weaned calves are given in Tables 3 and 4 respectively. The weight gain of the ruminant calves, in spite of their higher total dry-matter intake, was much lower than for the pre-ruminant calves.

\section{Table 3. Effect of environmental temperature and level of feeding on total dry-matter} intake and weight gain of calves given liquid diets (pre-ruminant calves)

(Mean values with their pooled standard errors)

\begin{tabular}{|c|c|c|c|c|c|c|c|c|}
\hline \multicolumn{9}{|c|}{ (Mean values with their pooled standard errors) Significance of effect } \\
\hline \multirow{3}{*}{$\begin{array}{l}\text { Treatment no. } \\
\text { Environmental temperature } \\
\left({ }^{\circ} \mathrm{C}\right)\end{array}$} & \multirow[b]{2}{*}{ I C } & \multirow[b]{2}{*}{$\mathbf{I} \mathbf{H}$} & \multirow[b]{2}{*}{$2 \mathrm{C}$} & \multirow[b]{2}{*}{${ }_{2} \mathrm{H}$} & $\begin{array}{l}\text { Pooled } \\
\text { SE of } \\
\text { mean }\end{array}$ & \multirow[t]{2}{*}{$\begin{array}{l}\text { Environ- } \\
\text { mental } \\
\text { tempera- } \\
\text { ture }\end{array}$} & \multirow[t]{2}{*}{$\begin{array}{l}\text { Level } \\
\text { of } \\
\text { feeding }\end{array}$} & \multirow[t]{2}{*}{$\begin{array}{l}\text { Inter- } \\
\text { action }\end{array}$} \\
\hline & & & & & & & & \\
\hline & 14.4 & $20 \cdot 6$ & 14.0 & $21 \cdot 0$ & & & & \\
\hline Relative humidity (\%) & & 46 & 63 & 48 & & & & \\
\hline Level of feeding & ad lib. & ad lib. & $\begin{array}{l}\text { Re- } \\
\text { stricted }\end{array}$ & $\begin{array}{l}\mathrm{Re}- \\
\text { stricted }\end{array}$ & & & & \\
\hline No. of calves & IO & 10 & IO & 10 & & & & \\
\hline Birth weight $(\mathrm{kg})$ & $33 \cdot 9$ & $34 \cdot I$ & 33.4 & $36 \cdot 3$ & $I \cdot I 9$ & - & - & 一 \\
\hline Total dry-matter intake (kg) & 124.9 & $126 \cdot 1$ & 120.4 & 113.0 & $5 \cdot 18$ & - & - & - \\
\hline Relative weight gain $\left(k \times 10^{2}\right) \dagger$ & $1 \cdot 30$ & $1 \cdot 29$ & $1 \cdot 27$ & $I \cdot 30$ & 0.067 & 一 & 一 & - \\
\hline $\begin{array}{l}\text { Adjusted for differences } \\
\text { between treatment } \\
\text { groups in mean total } \\
\text { dry-matter intake }\end{array}$ & $x \cdot 32$ & $1 \cdot 32$ & $1 \cdot 27$ & $\mathrm{r} \cdot 25$ & 0.061 & - & - & - \\
\hline Daily live-weight gain (kg) & 0.87 & 0.88 & 0.84 & 0.89 & 0.052 & - & - & - \\
\hline $\begin{array}{l}\text { Adjusted for differences } \\
\text { between treatment groups } \\
\text { in mean total dry-matter } \\
\text { intake }\end{array}$ & 0.89 & 0.90 & 0.84 & 0.85 & 0.048 & - & - & - \\
\hline+7 & $\underline{\log _{e} 1}$ & final weig & ght $(\mathrm{kg})-$ & $\log _{e}$ birt & weight $(1$ & & & \\
\hline
\end{tabular}

The mean daily dry-matter intakes plotted against live weight at weekly intervals for the pre-ruminant and ruminant calves given milk substitute ad lib. (treatments i $\mathrm{C}$ and ${ }_{I} \mathrm{H}$ ) or dry food $a d$ lib. (treatments ${ }_{3} \mathrm{C}$ and ${ }_{3} \mathrm{H}$ ), irrespective of environmental temperature, are shown separately for the three breeds in Fig. I. There was clearly no difference in daily dry-matter intake between the three breeds in relation to live weight when the calves were given milk substitute ad lib. However, in contrast, for the ruminant calves, there was a marked difference between breeds in daily dry-matter intake at a given weight, the Jersey breed having a much higher intake than the Ayrshire breed and the Ayrshire tending to have a higher intake than the Friesian breed. Moreover, the proportion of the dry food consumed as hay was inversely 
Table 4. Effect of environmental temperature and level of feeding on total dry-matter intake, water intake and weight gain of calves given dry diets (ruminant calves)

(Mean values with their pooled standard errors)

Significance of effect

\begin{tabular}{|c|c|c|c|c|c|c|c|c|}
\hline & & & & & & & & entect \\
\hline Treatment no. & ${ }_{3} \mathrm{C}$ & $3 \mathrm{H}$ & $4 \mathrm{C}$ & $4 \mathrm{H}$ & $\begin{array}{l}\text { Pooled } \\
\text { sE of } \\
\text { mean }\end{array}$ & $\begin{array}{l}\text { Environ- } \\
\text { mental } \\
\text { tempera- } \\
\text { ture }\end{array}$ & $\begin{array}{l}\text { Level } \\
\text { of } \\
\text { feeding }\end{array}$ & $\begin{array}{l}\text { Inter- } \\
\text { action }\end{array}$ \\
\hline $\begin{array}{l}\text { Environmental temperature } \\
\left({ }^{\circ} \mathrm{C}\right)\end{array}$ & $14 \cdot 8$ & $2 x \cdot 3$ & 14.8 & $21 \cdot 4$ & & & & \\
\hline Relative humidity (\%) & 66 & 50 & 64 & 49 & & & & \\
\hline No. of calves & IO & 10 & Io & 10 & & & & \\
\hline Birth weight $(\mathrm{kg})$ & $27 \cdot 7$ & $33 \cdot 7$ & $32 \cdot 5$ & $32 \cdot 7$ & $1 \cdot 33$ & * & - & * \\
\hline Total dry-matter intake $(\mathrm{kg}) \mathrm{fr}$ & from: & & & & & & & \\
\hline Milk substitute & $12 \cdot 4$ & 14.9 & $14 \% 3$ & I4.5 & 0.50 & * & - & $*$ \\
\hline Concentrates & $19 \cdot 3$ & $143 \cdot 2$ & $107 \cdot 9$ & $106 \cdot 5$ & 4.87 & * & $* * *$ & $*$ \\
\hline Hay & $6 \cdot 3$ & $7 \cdot 1$ & 10.8 & $10 \cdot 3$ & $I \cdot 3 I$ & - & $* *$ & - \\
\hline Total water intake $(\mathrm{kg})$ & $3 \circ 3$ & $48 i$ & 362 & 347 & $32 \cdot 6$ & $*$ & - & ** \\
\hline Relative weight gain $\left(k \times 10^{2}\right) \dagger$ & $1 \cdot 12$ & $\mathbf{I} \cdot 18$ & I.04 & I.04 & 0.045 & - & $*$ & - \\
\hline $\begin{array}{l}\text { Adjusted for differences } \\
\text { between treatment groups } \\
\text { in mean birth weight and } \\
\text { concentrate intake }\end{array}$ & $I \cdot 02$ & $\mathbf{I} \cdot \mathbf{I} \mathbf{2}$ & $I \cdot I I$ & $I \cdot I 2$ & 0.039 & - & - & - \\
\hline $\begin{array}{l}\text { Adjusted for differences } \\
\text { between treatment groups } \\
\text { in mean birth weight, } \\
\text { concentrate intake and } \\
\text { water intake }\end{array}$ & $I \cdot O \mathbf{I}$ & $\mathrm{I} \cdot \mathrm{I} 5$ & $I \cdot I I$ & $r \cdot 12$ & 0.039 & * & - & - \\
\hline Daily weight gain (kg) & 0.62 & 0.75 & 0.60 & 0.58 & 0.023 & * & $* * *$ & ** \\
\hline $\begin{array}{l}\text { Adjusted for differences } \\
\text { between treatment groups } \\
\text { in mean concentrate intake }\end{array}$ & 0.62 & 0.65 & 0.65 & 0.63 & 0.012 & - & - & 一 \\
\hline
\end{tabular}

* Significant at $P<0.05$.

Significant at $P<0.01$.

Significant at $P<0.001$.

$$
+k=\frac{\log _{e} \text { final weight }(\mathrm{kg})-\log _{e} \text { birth weight }(\mathrm{kg})}{\text { age }(\mathrm{d})} \text {. }
$$

related to the size of the breed, being 6.3, 4.5 and $3.9 \%$ for Jersey, Ayrshire and Friesian respectively. As a result of these findings, equal dry-matter intakes from liquid and dry food were achieved by the three breeds at the following live weights, given both in absolute terms and as a percentage of mature weight:

$\begin{array}{lcc}\text { Breed } & \text { Weight }(\mathrm{kg}) & \begin{array}{c}\text { Weight as } \\ \% \text { of mature } \\ \text { weight }\end{array} \\ \text { Jersey } & 36 \cdot 0 & 8 \cdot 8 \\ \text { Ayrshire } & 47 \cdot 5 & 8 \cdot 9 \\ \text { Friesian } & 52 \cdot 0 & 8 \cdot 4\end{array}$

The gross energy content of the milk substitute was $21 \times 10^{3} \mathrm{~J} \mathrm{~g}^{-1}\left(5^{\cdot 2} \mathrm{kcal} / \mathrm{g}\right) \mathrm{dry}$ matter (Roy, Stobo \& Gaston, I970) and that of the concentrate $18 \times \mathrm{IO}^{3} \mathrm{~J} \mathrm{~g}^{-1}$ $(4.4 \mathrm{kcal} / \mathrm{g})$ dry matter. Assuming that the values for net energy as a percentage of gross energy were 76 and 48 for the milk substitute and dry food respectively, equi- 


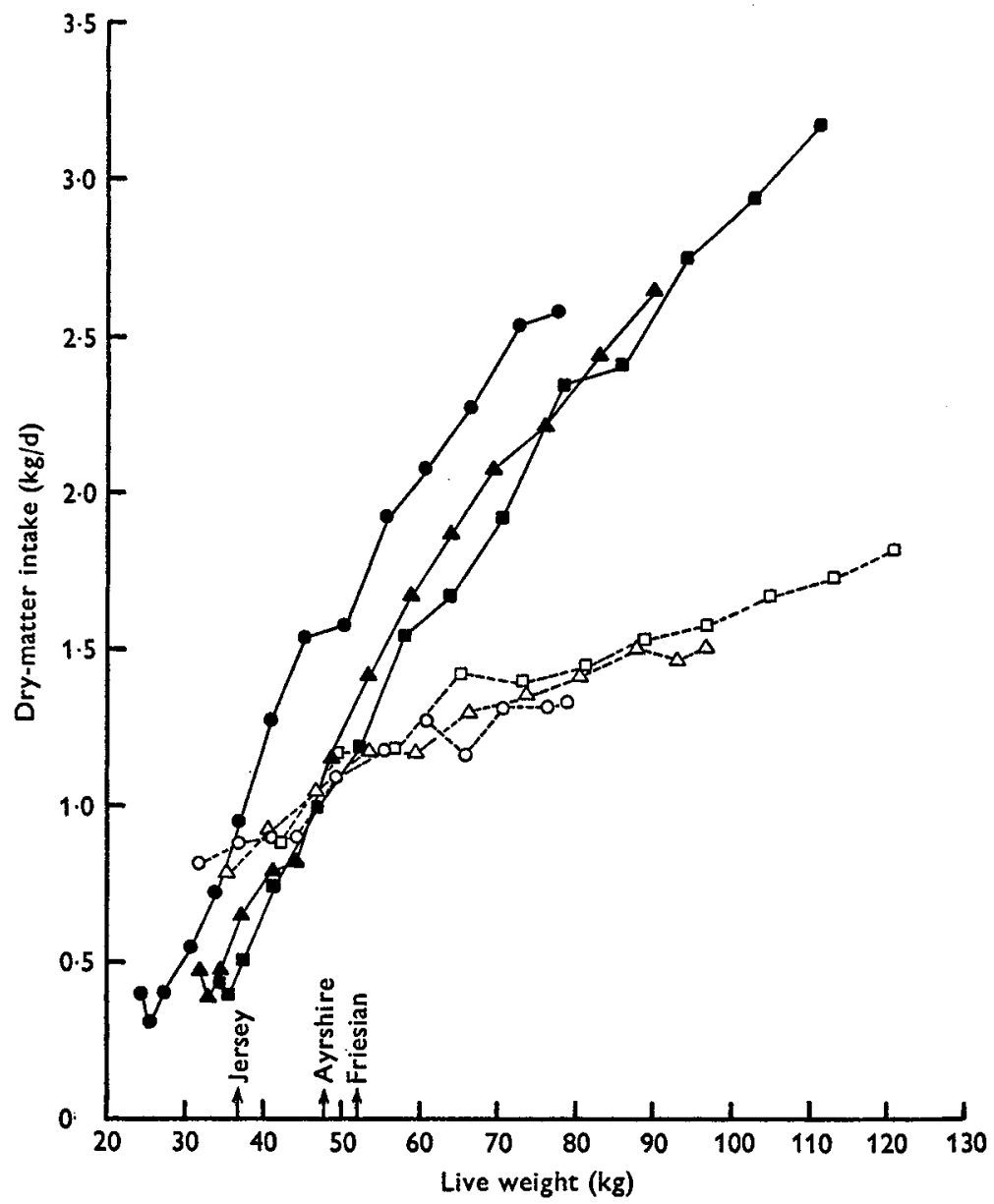

Fig. I. Dry-matter intake in relation to live weight for Jersey, Ayrshire and Friesian calves given a dry diet $a d l i b$. or a liquid diet ad lib. in two feeds daily. - , dry diet; - - -, liquid diet; $0, \boldsymbol{\rho}$, Jersey; $\Delta, \Delta$, Ayrshire; $\square, \square$, Friesian; $\uparrow$, live weight at which equal dry matter is ingested from liquid or dry diets for each of the three breeds.

valent net energy intakes were obtained from liquid and dry diets at the following live weights, given both in absolute terms and as a percentage of mature weight, for the three breeds:

$\begin{array}{lcc}\text { Breed } & \text { Weight (kg) } & \begin{array}{c}\text { Weight as } \\ \% \text { of mature } \\ \text { weight }\end{array} \\ \text { Jersey } & 70 & 17 \cdot 2 \\ \text { Ayrshire } & 94 & 17 \cdot 6 \\ \text { Friesian } & \text { I } 10 & \text { I } 7 \cdot 7\end{array}$

The live weight for Ayrshires was obtained by extrapolation of daily dry-matter intake from dry food since the calves on this treatment reached a mean live weight of only $90 \mathrm{~kg}$. In spite of the higher dry-matter intake from dry food at the same live weight for the Jersey breed, the relative weight gain $(k)$ to the same age did not differ from 
that of the Ayrshire breed. The relative weight gain $(k)$ was calculated from the following formula:

$$
k=\frac{\log _{e} \text { final weight }(\mathrm{kg})-\log _{e} \text { birth weight }(\mathrm{kg})}{\text { age }(\mathrm{d})} .
$$

For the pre-ruminant calves in which daily dry-matter intake at the same weight did not differ between breeds, the relative weight gain $\left(k \times 10^{2}\right)$ to the same percentage of mature weight also did not differ between the Jersey and Ayrshire breeds. The relative weight gain of the Friesians tended to be higher than that of the Jersey and of the Ayrshire when either liquid or dry diets were given. The relative weight gains $\left(k \times \mathrm{ro}^{2}\right)$ for the three breeds were:

$\begin{array}{lccc}\text { Mreed } & \begin{array}{c}\text { Milk substitute } \\ \text { ad lib. }\end{array} & \text { Dry food ad lib. } & \text { Pooled SE } \\ \text { Jersey } & \mathbf{I} \cdot 20 & \mathrm{I} \cdot 09 & 0.077 \\ \text { Ayrshire } & \mathrm{I} \cdot 28 & \mathrm{I} \cdot \mathbf{2} 2 & 0.044 \\ \text { Friesian } & \mathrm{I} \cdot 43 & \mathrm{I} \cdot 3 \mathrm{I} & 0.077\end{array}$

For the pre-ruminant calves, weight gain over the whole experimental period, expressed in either absolute terms or relative to birth weight, did not differ at the two environmental temperatures or with level of feeding.

For the ruminant calves, it was unfortunate that the mean birth weight of calves on treatment 3 in the 'cold' unit was significantly lower than for those of calves on the other three treatments. This resulted in part from a Jersey calf on this treatment that weighed only $15 \cdot 3 \mathrm{~kg}$ at birth. This low mean birth weight for treatment ${ }_{3} \mathrm{C}$ resulted in an apparent significantly lower intake of milk substitute and a significantly lower intake of concentrates and water. This, however, was an artifact, and environmental temperature probably had little effect on weight gain. That this was so was shown by the values for daily weight gain, adjusted for differences between treatment groups in mean concentrate intake; these adjusted values did not differ between treatments. However, adjustment of relative weight gain for differences between treatment groups in mean birth weight and concentrate intake, or for these two variables together with water intake, did not remove the tendency for a lower relative weight gain for calves on treatment ${ }_{3} \mathrm{C}$.

\section{Measurements made after slaughter}

The results, given in Table 5, show that age at slaughter did not differ between any of the treatments. Both carcass weight and carcass weight ${ }^{0.73}$ were significantly greater in the pre-ruminant calves and significantly greater for the 'hot' unit. The effect of temperature was small, and was probably associated in part with the low mean birth weight of the calves on treatment ${ }_{3} \mathrm{C}$. However, even when carcass weight was adjusted for differences between treatment groups in mean birth weight, it was still greater for the calves given dry food $a d l i b$. in the 'hot' unit than in the 'cold' unit.

Perirenal fat deposition was much greater for the pre-ruminant calves, greater for ad lib. feeding and greater at the high environmental temperature. This increase in fat deposition with increase in environmental temperature was $7-8 \%$ for calves 
Vol. 26 Effect of environmental temperature on calves

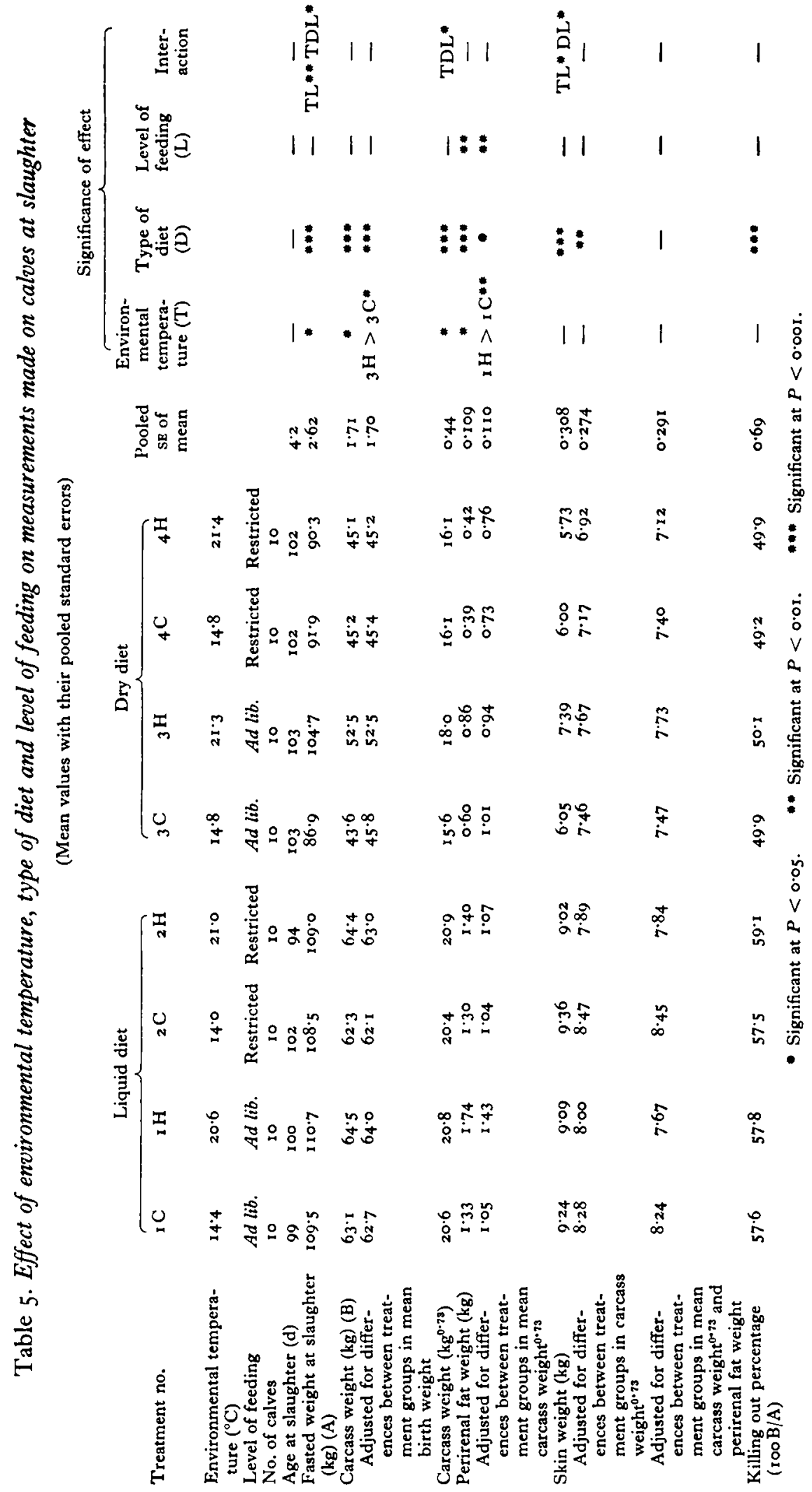


given food at the restricted level of intake, whether they were pre-ruminant or ruminant, and $3 \mathrm{I}$ and $43 \%$ for pre-ruminant and ruminant calves respectively given food ad lib. After adjustment for differences between treatment groups in mean carcass weight ${ }^{0.73}$, the effect of type of diet and level of feeding was still significant, but the effect of environmental temperature was only significant for the calves given milk substitute ad lib. The calves on this feeding regimen had a $36 \%$ higher perirenal fat deposition in the 'hot' compared with the 'cold' unit.

Weight of skin was significantly higher for the pre-ruminant calves. After adjustment for differences between treatment groups in mean carcass weight $t^{0.73}$, the difference in weight of skin was still apparent, but when adjusted for differences in both carcass weight $\mathrm{t}^{0.73}$ and perirenal fat deposition, the difference in skin weight was no longer significant.

Killing out percentage was much higher for the pre-ruminant calves but was unaffected by environmental temperature or level of feeding.

\section{DISCUSSION}

Although marked differences were observed between pre-ruminant and ruminant calves in health and performance, the different environmental temperatures appeared to have relatively little effect.

Mortality of calves and the incidence of diarrhoea were similar in the two units maintained at 14.5 and $21^{\circ}$ respectively, although the incidence of diarrhoea was, as expected, lower for the ruminant calves (Roy, $1969 a$ ). The lower incidence of a high rectal temperature and the lower mean rectal temperature for ruminant calves were probably related partly to their much lower plane of nutrition, owing to the inefficient utilization of dietary energy, and partly to their lower insulation against heat loss as a result of their thinner skins and smaller deposition of fat.

The greater incidence and severity of lung lesions in the ruminant than in the preruminant calf, and the tendency for a higher incidence and severity of lung lesions in calves reared at the high environmental temperature are of considerable interest.

The effect of 'early weaning' in predisposing calves to infection was suggested by Quarmby (1964), and, under range conditions in the USA, the first clinical signs of pneumonia appear shortly after weaning, at which time the calves are on a low plane of nutrition (Brown, 1968). However, weaning in the autumn also coincides with large variations between day and night temperatures. It is not known how far the effect of 'early weaning' in increasing the severity of and susceptibility to respiratory infection is due to the lower level of intake of productive energy or to the lower intake and utilization of some micro-nutrients. For instance, although the vitamin A intake together with the vitamin A equivalent of the carotene and cryptoxanthin intake, were considerably higher for the ruminant calves, utilization from the dry diets, which contained 9580 and 5667 i.u. vitamin $\mathrm{A} / \mathrm{kg}$ dry matter for concentrates and hay respectively, may well have been lower. The possibility that inhaled dust or fungal spores from the dry food may have exacerbated infections by viruses and bacteria cannot be discounted (Lacey, r968), especially since the incidence of lung lesions was 
found to be higher when calves were given hay in addition to a high level of milk substitute diet (Roy et al. I97I).

In relation to the effect of high environmental temperature on severity of lung lesions, Martin (1963) gives an example where efforts to increase temperature resulted in a severe outbreak of pneumonia, but this may have resulted more from a reduction in ventilation rate than from an effect of increased temperature per se.

The importance of an adequate ventilation rate and cubic capacity per calf in reducing the incidence of respiratory infections and mortality and improving growth rates has been frequently reported (Esmay, Williams \& Guyer, 1953; Martin, 1963; Quarmby, 1964; National Agricultural Advisory Service, 1964, 1965; Thompson, 1966; Martin, 1967). In the present experiment, both the ventilation rate and cubic capacity per calf were the same in both units and considerably above those attained under commercial conditions.

Practical experience indicates that a high relative humidity at a low temperature is associated with outbreaks of pneumonia, but there have been few controlled experiments on the subject. Workers in the USSR (Kovaleva, Zadarnovskaya \& Tarabrin, I96I) considered that a relative humidity of $83-97 \%$ was detrimental to the calf. In the present experiment, although mean relative humidity in the 'cold' unit was below those values, ranging from 55 to $76 \%$ for individual calves, nevertheless a positive relationship between the severity of lung lesions and relative humidity in the 'cold' unit was found for Jersey and Friesian but not for Ayrshire calves. In the 'hot' unit, however, Jersey and Friesian calves tended to develop less severe lung lesions if the relative humidity was high, which is in keeping with the policy of certain commercial veal producers to maintain their calves at both a high environmental temperature and a very high relative humidity as a preventive measure against pneumonia.

In an earlier experiment (Roy, Stobo \& Gaston, I970) a very much higher incidence of lung lesions was found for Friesian than for Ayrshire calves reared on liquid diets. The difference between breeds, both in the incidence of lung lesions and in the effect of relative humidity on the severity of lung lesions, in the present experiment may be associated with differences in insulation of the calves, since the skin weights of Jersey and Friesian calves at $20 \%$ of mature cow weight are very similar, being 266 and $267 \mathrm{~g} / \mathrm{kg}^{0.73}$ respectively, whereas the skins of Ayrshire calves are very significantly heavier at $298 \mathrm{~g} / \mathrm{kg}^{0} \cdot 73$ (Roy, Stobo \& Gaston, 1966, 1970). Further evidence for this is shown by the overall inverse relationship of severity of lung lesions and skin weight $/ \mathrm{kg}^{0.73}$ in the 'hot', but not in the 'cold', unit in the present experiment. This relationship would not appear to have resulted from a reduced fat deposition in the skin as a result of pyrexia of the calves with the most severe lesions, since no relationship between severity of lung lesions and perirenal fat deposition at slaughter was observed.

The rate of heat loss from the calves kept in cold air with a high relative humidity is likely to be greater than with a lower relative humidity, since the insulation afforded by the layer of air close to the body will be decreased especially at the high ventilation rates used in the present experiment. Since the calves of the Jersey and Friesian breeds also have thinner skins, the insulation of these calves will be even lower than 
for the Ayrshire calves. Jennings \& Glover (1952) found that calves that were chilled when artificially infected with respiratory viruses were more severely affected and showed more extensive lung lesions. The lack of effect of relative humidity on the Ayrshire breed may be due to their greater adaptability to cold environmental conditions, irrespective of the relative humidity, since their distribution in the world, unlike that of the Friesian and Jersey breeds, is largely in cold temperate climates. The overall relationship between severity of lung lesions and skin weight in the 'hot' unit was largely due to the lower skin weight of the ruminant calves, which had lung lesions of greater severity than the pre-ruminant calves.

'The overall regression equations for the Jersey and Friesian calves kept at the 'high' environmental temperature and combined from the two experiments were:

$$
\begin{array}{ll}
\text { Jersey }(n=\mathrm{II}) & Y=6 \cdot 24-0.060 x \quad(\mathrm{SD}=\mathrm{I} \cdot 76), \\
\text { Friesian }(n=9) & Y=\mathrm{II} \cdot 17-0.169 x \quad(\mathrm{SD}=\mathrm{I} \cdot 22), \\
\text { Jersey and Friesian }(n=20) & Y=7 \cdot 7 \mathrm{I}-0.096 x \quad(\mathrm{SD}=\mathrm{I} \cdot 58),
\end{array}
$$

where $Y=$ severity of lung lesions and $x=$ relative humidity ( $\%$ ).

In contrast, the results from the present experiment for Jersey and Friesian calves kept at the 'low' environmental temperature were:

$$
\begin{array}{lll}
\text { Jersey }(n=8) & Y=-7 \cdot 62+0 \cdot 130 x & (\mathrm{SD}=\mathrm{I} \cdot 22), \\
\text { Friesian }(n=7) & Y=-7 \cdot 5 \mathrm{I}+0 \cdot 134 x & (\mathrm{SD}=\mathrm{I} \cdot 87), \\
\text { Jersey and Friesian }(n=15) & Y=-7 \cdot 66+0 \cdot 133^{x} & (\mathrm{SD}=\mathrm{I} \cdot 44) .
\end{array}
$$

An estimate was made of the relative humidity at which no lung lesions or the most severe lung lesions would occur for calves maintained at either the 'low' or 'high' environmental temperature. These estimates are shown in Fig. 2 together with their standard errors for the Jersey and Friesian breeds separately and combined. Since the relationship between severity of lung lesions and relative humidity was positive at the 'low' environmental temperature and negative at the 'high' environmental temperature, it is suggested that there is an optimum temperature at which extremes of relative humidity have a minimal effect in predisposing calves to lung lesions. This temperature would appear to be a little over $17^{\circ}$.

However, this hypothesis must be treated with caution since the total number of Jersey and Friesian calves involved was only thirty-five, and we have no information on the relationship between severity of lung lesions and relative humidity at environmental temperatures intermediate between those studied in these two experiments.

Besides the clear difference in weight gain between ruminant and pre-ruminant calves, there was certainly no effect of environmental temperature on the weight gain of pre-ruminant calves or on that of the ruminant calves on restricted food intake. The apparent increase in weight gain for ruminant calves given food ad lib. in the 'hot', compared with the 'cold', unit was probably mainly associated with the significantly lower mean birth weight of the calves in the 'cold' unit on this treatment, an effect on live-weight gain that could not be entirely removed by covariance analysis. 


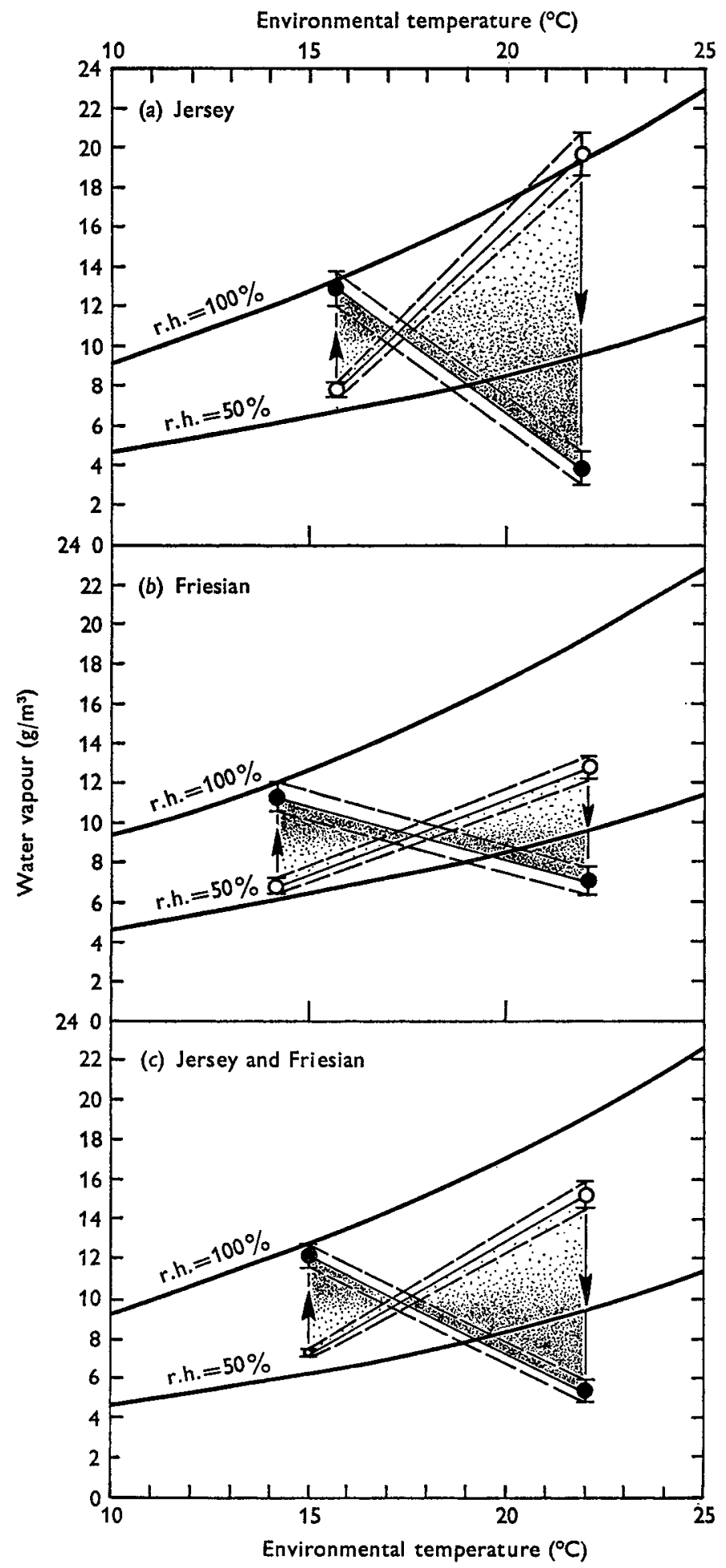

Fig. 2. Predicted value for relative humidity (r.h.) at which the most severe lung lesions and no lung lesions occur in Friesian and Jersey calves at different environmental temperatures, together with a predicted environmental temperature at which changes in relative humidity are least likely to influence the severity of lung lesions. $\Phi$, no lung lesions with its standard error; $\$$, most severe lung lesions with its standard error; $\uparrow$, direction of increase in severity of lung lesions. 
Even during the first 3 weeks of life, there was no evidence of an effect of environmental temperature on weight gain. Since the average temperature in the 'cold' unit was above the critical temperature of the calf, as found by Gonzalez-Jimenez \& Blaxter (1962), the absence of an effect was not surprising.

The finding that, when a milk substitute was given ad lib. in two feeds daily, there was no difference between breeds in mean daily dry-matter intake at a given live weight confirms the results obtained in an earlier experiment (Roy, I967). In ruminant calves, no difference between breeds in daily dry-matter intake at a given live weight was expected, but the higher intakes observed with calves of the smaller breeds in the present experiment confirm a suggestion to this effect made by Dr St C. S. Taylor (1970, personal communication). Thus, similar intakes of dry matter can be obtained from dry or liquid diets at the same percentage of mature live weight $(8-9 \%)$ for the different breeds, rather than at a constant live weight. In an earlier experiment (Roy, $1969 b$ ), the dry-matter intake of Friesian calves was less from dry diets given $a d$ lib. than from liquid diets until $70 \mathrm{~kg}$ live weight. In the present experiment, the Friesian calves obtained equal intakes of dry matter from liquid and from dry diets at $52 \mathrm{~kg}$ live weight, although in both experiments similar net energy intakes were achieved at about I Io kg live weight.

Despite the higher daily dry-matter intake of dry food per unit of live weight by calves of the Jersey breed, relative weight gain was similar to that of the Ayrshire calves given dry food. It is probable that the greater quantity of roughage consumed by the Jersey calves reduced the digestibility of the diet and also resulted in a lower net availability of the metabolizable energy of the diet. Relative weight gain was also similar for the Jersey and Ayrshire calves given liquid diets, but this was to be expected, as daily dry-matter intake in relation to live weight did not differ between breeds. The tendency for a higher relative growth rate of the Friesian calves was expected, since this has been demonstrated previously (Roy, 1967), and appears to be related to the higher muscle to bone ratio of the Friesian breed.

The lower carcass weight and killing out percentage for the ruminant calves was a reflection of their lower weight gains and fat deposition and also of the lower gut fill of the pre-ruminant calves (Roy et al. 1964; Stobo, Roy \& Gaston, 1966). Although it appeared that perirenal fat deposition was markedly increased at the high environmental temperature for both pre-ruminant and ruminant calves fed ad lib., after covariance adjustment for differences in carcass weight ${ }^{0 \cdot 73}$, it was clear that the only real effect of temperature was on the pre-ruminant calves, which showed a $36 \%$ increase in deposition of perirenal fat. From the values of Barton \& Kirton (1961), an estimate of the total and percentage fat in the carcasses of the calves on the eight treatments was made, and the values were:

\begin{tabular}{|c|c|c|c|c|c|c|c|c|}
\hline & \multicolumn{4}{|c|}{ Liquid diet } & \multicolumn{4}{|c|}{ Dry diet } \\
\hline & $\begin{array}{c}\text { (1 C) } \\
a d \\
\text { lib. }\end{array}$ & $\begin{array}{c}(\mathrm{r} \mathrm{H}) \\
a d \\
l i b .\end{array}$ & $\begin{array}{c}(2 \mathrm{C}) \\
\text { Re- } \\
\text { stricted }\end{array}$ & $\begin{array}{c}(2 \mathrm{H}) \\
\mathrm{Re}- \\
\text { stricted }\end{array}$ & $\begin{array}{l}(3 \mathrm{C}) \\
a d \\
\text { lib. }\end{array}$ & $\begin{array}{c}(3 \mathrm{H}) \\
a d \\
l i b .\end{array}$ & $\begin{array}{c}(4 \mathrm{C}) \\
\mathrm{Re}- \\
\text { stricted }\end{array}$ & $\begin{array}{c}(4 \mathrm{H}) \\
\mathrm{Re}- \\
\text { stricted }\end{array}$ \\
\hline $\begin{array}{l}\text { Total }(\mathrm{kg}) \\
\text { Percentage }\end{array}$ & $\begin{array}{l}5.6 \\
8.8\end{array}$ & $\begin{array}{r}7 \cdot 3 \\
1 \times \cdot 3\end{array}$ & $\begin{array}{l}5 \cdot 4 \\
8.7\end{array}$ & $\begin{array}{l}5 \cdot 9 \\
9 \cdot I\end{array}$ & $\begin{array}{l}2.5 \\
5.8\end{array}$ & $\begin{array}{l}3.6 \\
6.9\end{array}$ & $\begin{array}{l}1.6 \\
3.6\end{array}$ & $\begin{array}{l}I \cdot 8 \\
3.9\end{array}$ \\
\hline
\end{tabular}


Although level of feeding affected fat deposition in the ruminant calves, for the pre-ruminant calves the results at the two levels of feeding did not differ sufficiently to show any effect in the 'cold' unit. Although the major effect of environmental temperature on fat deposition was with the pre-ruminant calves with the highest energy intake (treatment $\mathrm{IH}$ ), nevertheless fat deposition tended to increase at the high environmental temperature with all feeding regimens.

The lower skin weight of the ruminant calves, even after adjustment for differences between treatment mean for carcass weight ${ }^{0.73}$, appeared to be associated with the reduced deposition of fat in the carcass, since adjustment for both carcass weight ${ }^{0.73}$ and deposition of perirenal fat resulted in the difference between ruminant and pre-ruminant calves being no longer apparent. Even after this adjustment, the preruminant calves apparently tended to have lower skin weights at the high environmental temperature.

From the results of this experiment, it can be concluded that there is no advantage in maintaining a calf-house at an environmental temperature above $14.5^{\circ}$, except for the production of veal calves in which a high deposition of fat may be required. The results have also shown some marked differences between ruminant and pre-ruminant calves, which suggests that the early weaning system may predispose calves to a higher incidence and greater severity of lung lesions from pneumonia than occur when calves receive a plentiful supply of milk.

\section{REFERENCES}

Barton, R. A. \& Kirton, A. H. (r96r). Anim. Prod. 3, 4r.

Blaxter, K. L. \& Wood, W. A. (195I). Br. F. Nutr. 5, 55.

Brown, W. W. (1968). J. Am. vet. Med. Ass. r52, 726.

Esmay, M. L., Williams, H. F. \& Guyer, B. E. (1953). Res. Bull. Mo. agric. Exp. Stn no. 527.

Foot, A. S. \& Roy, J. H. B. (1967). Cattle in Chambers Encyclopaedia 4th ed. London: Chambers.

Gonzalez-Jimenez, E. \& Blaxter, K. L. (1962). Br. J. Nutr. r6, 199.

Haartsen, P. I., van Hellemond, K. K., van der Wal, P. \& van Weerden, E. J. (1967). Landbouwk. Tijdschr. 79, 323.

Jennings, A. R. \& Glover, R. E. (1952). F. comp. Path. 62, 6.

Kovaleva, V. N., Zadarnovskaya, A. F. \& Tarabrin, P. A. (196r). Trudy Saratov. zootekh. vet. Inst. 1o, 203.

Lacey, J. (1968). F. gen. Microbiol. 51, I73.

Martin, B. ( 1963$)$. Vet. Rec. 75, 78.

Martin, H. (1967). Vet. Rec. 8r, 255 .

National Agricultural Advisory Service (1964). Rep. Drayton exp. Husb. Fm p. 14.

National Agricultural Advisory Service (1965). Rep. Drayton exp. Husb. Fm p. 16.

Quarmby, W. B. (1964). Vet. Rec. 76, 590.

Roy, J. H. B. (1967). Sb. vys. Sk zemed. Brne 36, 325.

Roy, J. H. B. (1969a). International Encyclopaedia of Food and Nutrition Vol. I7, Part 2, p. 649. Oxford: Pergamon Press.

Roy, J. H. B. (1969b). Proc. Nutr. Soc. 28, г6o.

Roy, J. H. B., Gaston, H. J., Shillam, K. W. G., Thompson, S. Y., Stobo, I. J. F. \& Greatorex, J. C. (1964). Br. Y. Nutr. I8, 467.

Roy, J. H. B., Stobo, I. J. F. \& Gaston, H. J. (1965). Dairy Fmr, Ipswich 12, no. 7, p. 6r.

Roy, J. H. B., Stobo, I. J. F. \& Gaston, H. J. (1966). Rep. natn. Inst. Res. Dairy p. 5 I.

Roy, J. H. B., Stobo, I. J. F. \& Gaston, H. J. (1970). Br. F. Nutr. 24, 459.

Roy, J. H. B., Stobo, I. J. F., Gaston, H. J., Ganderton, P., Shotton, S. M. \& Thompson, S. Y. (I97I). Br. F. Nutr. 26, 353 .

Roy, J. H. B., Stobo, I. J. F., Gaston, H. J. \& Greatorex, J. C. (1970). Br. F. Nutr. 24, 44I.

Stobo, I. J. F., Roy, J. H. B. \& Gaston, H. J. (I966). Br. F. Nutr. 20, I7I.

Thompson, W. A. (1966). Agriculture, Lond. 73, 37. 